Article

\title{
Characteristics of Water Isotopes and Water Source Identification During the Wet Season in Naqu River Basin, Qinghai-Tibet Plateau
}

\author{
Xi Chen ${ }^{1}$, Guoli Wang ${ }^{1}$, Fuqiang Wang ${ }^{2,3, *}$, Denghua Yan ${ }^{4}$ and Heng Zhao ${ }^{2,3}$ \\ 1 School of Hydraulic Engineering, Dalian University of Technology, Dalian 116024, China; \\ chenxi218@mail.dlut.edu.cn (X.C.); wanggl@dlut.edu.cn (G.W.) \\ 2 Department of Water Conservancy Engineering, North China University of Water Resources and Electric \\ Power, Zhengzhou 450046, China; zhaoheng@ncwu.edu.cn \\ 3 Collaborative Innovation Center of Water Resources Efficient Utilization and Support Engineering, \\ Zhengzhou 450046, China \\ 4 Water Resources Department, China Institute of Water Resources and Hydropower Research, Beijing 100038, \\ China; yandh@iwhr.com \\ * Correspondence: wangfuqiang@ncwu.edu.cn; Tel.: +86-137-0371-4661
}

Received: 8 October 2019; Accepted: 15 November 2019; Published: 18 November 2019

check for updates

\begin{abstract}
Climate change is affecting the discharge of headstreams from mountainous areas on the Qinghai-Tibet Plateau. To constrain future changes in discharge, it is important to understand the present-day formation mechanism and components of runoff in the basin. Here we explore the sources of runoff and spatial variations in discharge through measurements of $\delta^{2} \mathrm{H}$ and $\delta^{18} \mathrm{O}$ in the Naqu River, at the source of the Nu River, on the Qinghai-Tibet plateau, during the month of August from 2016 to 2018. We established thirteen sampling sites on the main stream and tributaries, and collected 39 samples from the river. We examined all the water samples and analyzed them for isotopes. We find a significant spatial variation trend based on one-way analysis of variance (ANOVA) $(p<0.05)$ between Main stream-2 and tributaries. The local meteoric water-line (LMWL) can be described as: $\delta^{2} \mathrm{H}=7.9 \delta^{18} \mathrm{O}+6.29$. Isotopic evaporative fractionation in water and mixing of different water sources are responsible for the spatial difference in isotopic values between Main stream-2 and tributaries. Based on isotopic hydrograph separation, the proportion of snowmelt in runoff components ranges from $15 \%$ to $47 \%$, and the proportion of rainwater ranges from $3 \%$ to $35 \%$. Thus, the main components of runoff in the Naqu River are snowmelt and groundwater.
\end{abstract}

Keywords: stable isotopes; spatial variations; hydrograph separation; Naqu River basin; Qinghai-Tibet Plateau

\section{Introduction}

The gradual trend of global warming will affect the discharge of headstreams to plateau rivers, including on the Qinghai-Tibet Plateau [1-4]. Therefore, it is important to explore the formation mechanism and identify the components of runoff on the Qinghai-Tibet Plateau [5,6].

The Naqu River basin is sensitive to environmental change due to its high altitude. Studying its water cycle is not straightforward due to the lack of hydrological data and harsh natural conditions. Meanwhile, little is known about the water source contribution and the mechanism of the runoff. To constrain future changes in discharge, it is important to understand the present-day formation mechanism and components of runoff in the basin.

There are many methods to identify runoff components [7-13]. Recent studies have shown that hydrograph separation based on stable isotopes is an effective way to study the runoff 
mechanism [14-16]. In general, river components can be divided into precipitation, groundwater, soil water, and snowmelt based on isotope hydrological separation [17-25]. For example, based on the isotopic values of river waters, significant spatial and temporal variations of the Xijiang River were investigated [26]; Kong et al. found that the snowmelt water accounted for more than $57 \%$ of runoff of the Kumalak River [1], and more than 53\% during the wet season [6]. Based on isotopes and geochemical tracers, streams in plateau regions are mainly replenished by snowmelt and groundwater [27-38]. There has been relatively little research on the composition and mechanism of water sources on the Qinghai-Tibet Plateau. The advantages of isotope techniques in the hydrologic cycle are obvious and water samples can be obtained easily in the plateau region due to the lack of hydrological and meteorological data [18].

In this study, we analyze the spatial variation of isotopes in the runoff and compute the proportions of runoff components in the month of August based on hydrograph separation. We hope that the research results of this paper will provide a relevant theoretical basis for the formation mechanism of runoff on the Qinghai-Tibet Plateau.

\section{Study Areas}

The Naqu River basin is the source of the Nu River in southwest China (Figure 1). The Naqu River has several main tributaries, such as the Najinqu, Sangqu, Bazongqu, Mumuqu, Chengqu, Zongqungqu, Mugequ, and Gongqu Rivers. There are many seasonal streams and mountain streams flowing into the Naqu River. The average annual temperature in this area is $-0.6{ }^{\circ} \mathrm{C}$. The drainage area of the Naqu River basin is $16,350 \mathrm{~km}^{2}$, at a high altitude of $4600 \mathrm{~m}$ above sea level [39].

Annual precipitation is $531 \mathrm{~mm}$. From May to October, precipitation accounts for about $82 \%$ of the total annual rainfall, with less precipitation from November to April. Although there is not a significant amount of snowfall throughout the whole year, snowmelt has a strong replenishment effect on the runoff in the flood season. The climate is affected by Indian Ocean southwest monsoon in summer. The water vapor of precipitation comes from water vapor that evaporated under wetter conditions. This is consistent with summer southwest monsoon precipitation in the region coming directly from the Bay of Bengal. The d-excess value in the precipitation directly from the Bay of Bengal is lower due to the high relative humidity of the sea surface [37-42]. For this reason, the precipitation is coincident with the annual peak of snowmelt during the wet season. And they become the main components of runoff in the Naqu River basin. 


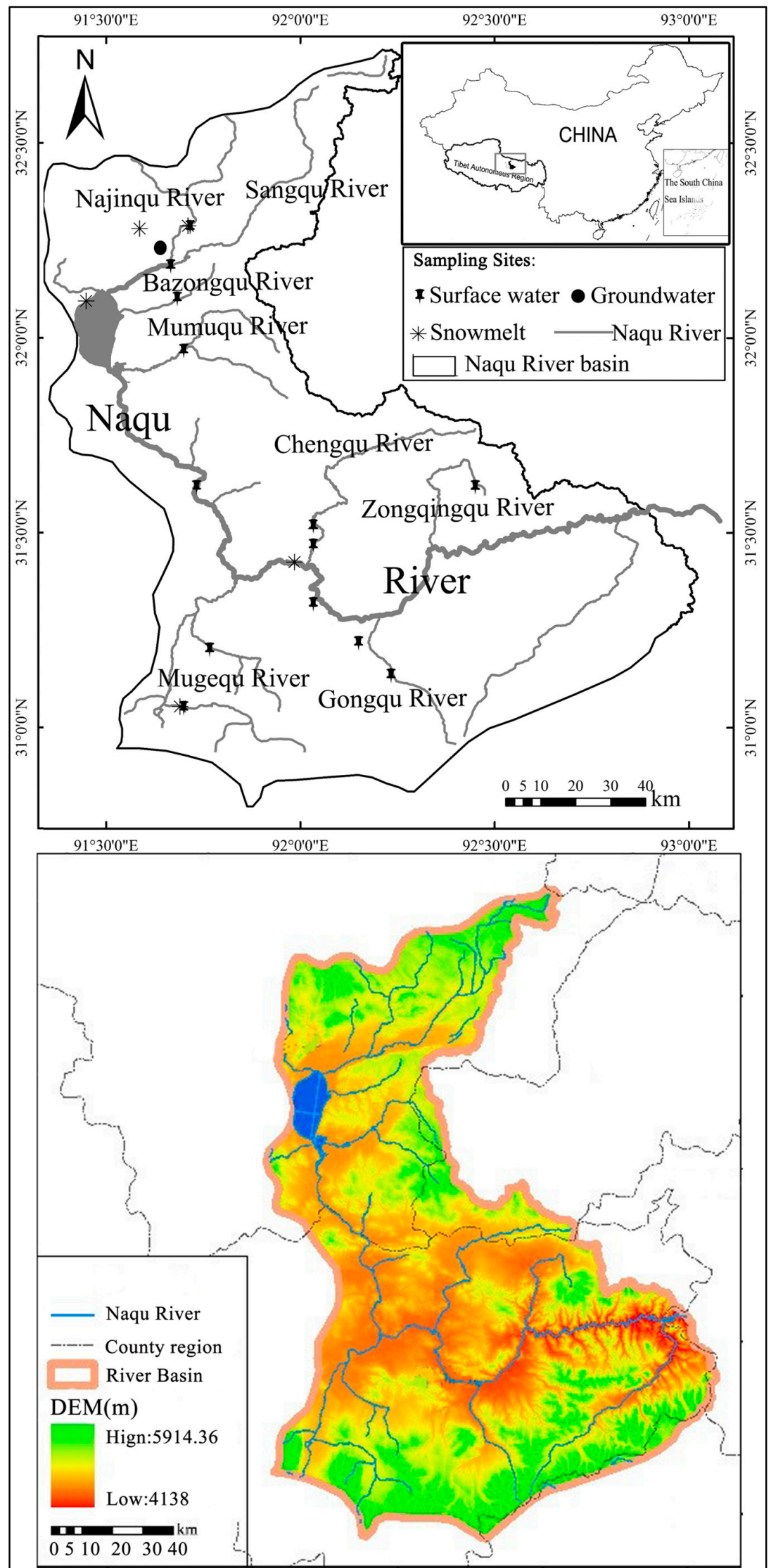

Figure 1. Research area and geographic location. 


\section{Materials and Methods}

\subsection{Field Sampling}

We installed thirteen sampling sites on the main stream and tributaries of the Naqu River, with the sampling sites of Main stream-1 and Main stream-2 along the main channel, and Najinqu, Sangqu, Bazongqu, Mumuqu, Chengqu, Zongqungqu, Mugequ, and Gongqu on eight tributaries (Figure 1). We collected a total of 39 samples from the river in the month of August from 2016 to 2018.

In general, water samples included 39 runoff samples, two groundwater samples, two rain samples, and five snowmelt samples during the wet season from 2016 to 2018 . We collected two rain samples on 13 August 2018.

\subsection{Measurement}

$\delta^{18} \mathbf{O}$ and $\delta^{2} \mathbf{H}$ analysis: Wavelength-scanned cavity ring down spectroscopy (WS-CRDS) (Picarro L1115-I, Picarro, Santa Clara, CA, USA) was used to measure water isotope composition, which were corrected using the Vienna Standard Mean Ocean Water (VSMOW, $\delta^{2} \mathrm{H}=0 \%$, $\delta^{18} \mathrm{O}=0 \%$ ) and Standard Light Antarctic Precipitation $\left(\delta^{2} \mathrm{H}=-428 \%\right.$ o, $\delta^{18} \mathrm{O}=-55.5 \%$ ). The analytical precision was generally $0.5 \%$ o for $\delta^{2} \mathrm{H}$ and $0.1 \%$ for $\delta^{18} \mathrm{O}$ [39]. The $\delta^{18} \mathrm{O}$ and $\delta^{2} \mathrm{H}$ values are expressed as follows:

$$
\begin{gathered}
\delta^{2} \mathrm{H}_{\mathrm{V}-\mathrm{SMOW}}=\left(\frac{{ }^{2} \mathrm{H} /{ }^{1} \mathrm{H}_{\text {sample }}}{{ }^{2} \mathrm{H} /{ }^{1} \mathrm{H}_{\text {standard }}}-1\right) \times 1000(\% \mathrm{o}) \\
\delta^{18} \mathrm{O}_{\mathrm{V}-\mathrm{SMOW}}=\left(\frac{{ }^{18} \mathrm{O} /{ }^{16} \mathrm{O}_{\text {sample }}}{{ }^{18} \mathrm{O} /{ }^{16} \mathrm{O}_{\text {standard }}}-1\right) \times 1000(\% \mathrm{o})
\end{gathered}
$$

EC analysis: Electrical conductivity (EC) was measured in situ with a conductivity meter. EC was measured concurrently with stream sampling using a standard conductivity cell (WTW Cond 340iTM). The standard conductivity cell was calibrated to correct for water temperature to $25^{\circ} \mathrm{C}$.

D-excess calculation: The deuterium excess (d-excess) was used to measure the isotopic variability [19] and is defined as:

$$
\text { d-excess }=\delta^{2} \mathrm{H}-8 \times \delta^{18} \mathrm{O}
$$

\subsection{Data Analysis}

We explored the spatial characteristics of the isotopes based on one-way analysis of variance (ANOVA) by using SPSS 17.0. Isotopic contents in water bodies of different main stream tributaries are expressed by box plot. ArcGIS of ESRI is applied to display spatial features of the Naqu River basin based on inverse distance weighting (IDW).

We analyzed samples for the two tracers collected from snowmelt, rain, stream water, and groundwater. Respecting the water and tracer mass conservation, electrical conductivity was measured in situ with a conductivity meter. The percentage of different components in the total runoff was determined using isotope hydrologic separation. If we suppose the objective percentage of $n$ components are evaluated based on $n$ parts and $n-1$ measuring factors $t_{1}, t_{2}, \cdots, t_{n-1}$, there are $n$ linear mixing equations. These are defined as follows:

$$
\begin{gathered}
Q_{T}=Q_{1}+Q_{2}+\cdots+Q_{n} \\
C_{T}^{t_{i}} Q_{T}=C_{1}^{t_{i}} Q_{1}+C_{2}^{t_{i}} Q_{2}+\cdots+C_{n}^{t_{i}} Q_{n}
\end{gathered}
$$

where $Q_{T}$ is the total flow of the river; $Q_{1}, Q_{2}, \cdots, Q_{n}$ represent the flows of different water sources of runoff, and $C_{1}^{t_{1}}, C_{2}^{t_{2}}, \cdots, C_{i}^{t_{i}}$ represent the concentrations of relevant observed tracer $t_{i}$. 
When the runoff contains only two sources of water, the percentages of different components of the runoff can be expressed as follows:

$$
\begin{aligned}
& Q_{1} / Q_{s}=\left(C_{2}-C_{s}\right) /\left(C_{2}-C_{1}\right) \\
& Q_{2} / Q_{s}=\left(C_{s}-C_{1}\right) /\left(C_{2}-C_{1}\right)
\end{aligned}
$$

where $Q$ is the runoff of each component, $C$ is the concentrations of relevant observed tracer, and $s$ is the total flow.

When the runoff contains only three sources of water, groundwater, snowmelt, and precipitation are the main components of runoff in August in the Naqu River basin. Hydrograph separation is used to calculate the various composition of the runoff based on two tracers $\left(\delta^{2} \mathrm{H}\right.$ and EC). Supposing the river flow is a function of snowmelt, groundwater, and precipitation, then the three-component sources model can be defined as follows:

$$
\begin{gathered}
f_{p}+f_{g}+f_{m}=1 \\
f_{p} Q_{p}+f_{g} Q_{g}+f_{m} Q_{m}=Q_{r} \\
f_{p} E_{p}+f_{g} E_{g}+f_{m} E_{m}=E_{r}
\end{gathered}
$$

where $f_{p}, f_{g}, f_{m}$ represent the shares of the individual components in the total runoff, and $Q$ and $E$ represent the concentrations of tracers.

\section{Results}

\subsection{Spatial Characteristics of $\delta^{18} \mathrm{O}$ and $\delta^{2} \mathrm{H}$}

In August 2017, $\delta^{18} \mathrm{O}$ values of runoff vary from $-15.6 \%$ o to $-10.5 \%$ o with a mean of $-15.49 \%$. The $\delta^{18} \mathrm{O}$ values of snowmelt water range from $-15.0 \%$ ond $-7.6 \%$ o with an average of $-11.4 \%$ o. The $\delta^{18} \mathrm{O}$ values of runoff vary from $-15.49 \%$ o to $-14.27 \%$ o (Table 1 ). For groundwater, the $\delta^{18} \mathrm{O}$ values are relatively stable, ranging from $-19.03 \%$ o to $-17.66 \%$, which indicated that the surrounding environment had little influence on groundwater and the recharge source of groundwater was relatively stable (Table 1).

Table 1. Oxygen isotope composition of different types of water in the Naqu River basin.

\begin{tabular}{ccccc}
\hline Water type & & $\mathbf{2 0 1 6 . 8}$ & $\mathbf{2 0 1 7 . 8}$ & $\mathbf{2 0 1 8 . 8}$ \\
\hline Stream water & Sample number & 13 & 13 & 13 \\
& Mean of $\delta^{18} \mathrm{O}(\%$ o $)$ & -14.27 & -15.49 & -14.83 \\
\hline Water type & & $\mathbf{3}$ 2016-2018 \\
\hline Snowmelt water & Sample number & 5 \\
Groundwater & Mean of $\delta^{18} \mathrm{O}(\%$ o & -11.37 \\
& Sample number & 2 \\
Rain & Mean of $\delta^{18} \mathrm{O}(\%$ o $)$ & -18.51 \\
& Sample number & 2 \\
& Mean of $\delta^{18} \mathrm{O}(\%$ o $)$ & -18.35 \\
\hline
\end{tabular}

The results of elevation effect analysis on the collected rivers (Table 2) show that the isotopes in runoff do not change with elevation (Figure 2). All values are plotted against altitude. We hypothesize that the water body experienced intense evaporative fractionation due to the slow river flow rate in the Naqu River basin. 
Table 2. Average values of $\delta^{2} \mathrm{H}$ and $\delta^{18} \mathrm{O}$ of main streams and tributaries.

\begin{tabular}{cccccccc}
\hline Location & $\begin{array}{c}\text { Sampling } \\
\text { Sites }\end{array}$ & $\begin{array}{c}\text { Sample } \\
\text { Number }\end{array}$ & $\begin{array}{c}\boldsymbol{\delta}^{\mathbf{1 8}} \mathbf{O} \\
\mathbf{( \% )}\end{array}$ & $\begin{array}{c}\boldsymbol{\delta}^{\mathbf{2}} \mathbf{H} \\
\mathbf{( \% \mathbf { o }}\end{array}$ & $\begin{array}{c}\text { Longtitude } \\
\mathbf{( E )}\end{array}$ & $\begin{array}{c}\text { Latitude } \\
\mathbf{( N )}\end{array}$ & $\begin{array}{c}\text { Altitude } \\
(\mathbf{m} \text { a.s.1.) }\end{array}$ \\
\hline Main stream-1 & 4 & 3 & -15.68 & -118.58 & $92^{\circ} 02^{\prime} 38.7^{\prime \prime}$ & $31^{\circ} 19^{\prime} 52^{\prime \prime}$ & 4451 \\
Main stream-2 & 8 & 3 & -15.48 & -116.32 & $91^{\circ} 44^{\prime} 17.7^{\prime \prime}$ & $31^{\circ} 37^{\prime} 15.2^{\prime \prime}$ & 4551 \\
Bazongqu & 9 & 3 & -16.88 & -124.93 & $91^{\circ} 42^{\prime} 51.9^{\prime \prime}$ & $31^{\circ} 58^{\prime} 40.2^{\prime \prime}$ & 4622 \\
Chengqu & 3 & 3 & -16.37 & -124.20 & $92^{\circ} 03^{\prime} 34.9^{\prime \prime}$ & $31^{\circ} 29^{\prime} 44.7^{\prime \prime}$ & 4503 \\
& 13 & 3 & -17.03 & -127.50 & $92^{\circ} 02^{\prime} 19.3^{\prime \prime}$ & $31^{\circ} 31^{\prime} 39.5^{\prime \prime}$ & 4519 \\
Gongqu & 5 & 3 & -15.83 & -119.46 & $92^{\circ} 09^{\prime} 30.5^{\prime \prime}$ & $31^{\circ} 13^{\prime} 32.5^{\prime \prime}$ & 4498 \\
& 6 & 3 & -16.21 & -121.16 & $92^{\circ} 14^{\prime} 23.2^{\prime \prime}$ & $31^{\circ} 08^{\prime} 21.8^{\prime \prime}$ & 4578 \\
Mugequ & 2 & 3 & -15.17 & -113.81 & $91^{\circ} 41^{\prime} 23.3^{\prime \prime}$ & $31^{\circ} 3^{\prime} 17.9^{\prime \prime}$ & 4681 \\
& 14 & 3 & -15.26 & -115.65 & $91^{\circ} 46^{\prime} 33.3^{\prime \prime}$ & $31^{\circ} 11^{\prime} 56^{\prime \prime}$ & 4591 \\
Mumuqu & 10 & 3 & -14.97 & -113.63 & $91^{\circ} 41^{\prime} 23.4^{\prime \prime}$ & $32^{\circ} 06^{\prime} 5.1^{\prime \prime}$ & 4712 \\
Najinqu & 12 & 3 & -14.81 & -111.99 & $91^{\circ} 42^{\prime} 38.5^{\prime \prime}$ & $32^{\circ} 22^{\prime} 30.3^{\prime \prime}$ & 4771 \\
Sangqu & 11 & 3 & -14.57 & -111.32 & $91^{\circ} 40^{\prime} 44.3^{\prime \prime}$ & $32^{\circ} 11^{\prime} 22^{\prime \prime}$ & 4626 \\
Zongqingqu & 7 & 3 & -13.18 & -103.02 & $92^{\circ} 25^{\prime} 42.2^{\prime \prime}$ & $31^{\circ} 41^{\prime} 12.6^{\prime \prime}$ & 4567 \\
\hline
\end{tabular}

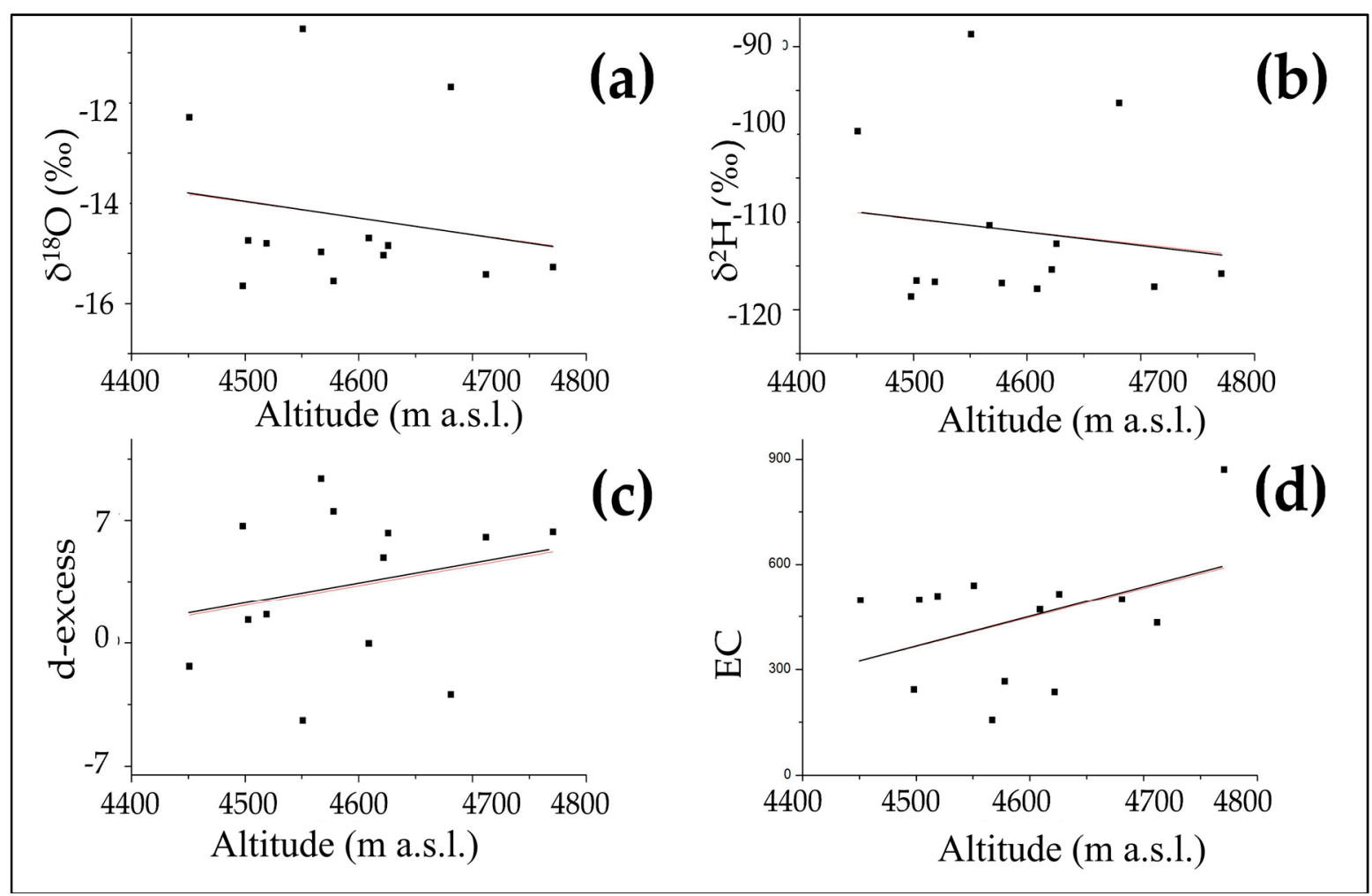

Figure 2. (a) $\delta^{18} \mathrm{O}$ altitude, (b) $\delta^{2} \mathrm{H}$ altitude, (c) d-excess altitude, and (d) electrical conductivity (EC) altitude relationship.

$\delta^{18} \mathrm{O}$ and $\delta^{2} \mathrm{H}$ values are shown in box plots for all the sampling sites (Figure 3 ).

Our analysis showed a significant spatial trend based on one-way ANOVA $(p<0.05)$ at 13 sampling sites between Main stream-2 and tributaries (Najinqu, Sangqu, Bazongqu, Mumuqu, Chengqu, Zongqungqu, Mugequ, and Gongqu). We speculate that isotopic evaporative fractionation in water and mixing of different water sources are the reasons for the spatial difference in isotopic values between Main stream-2 and tributaries. 


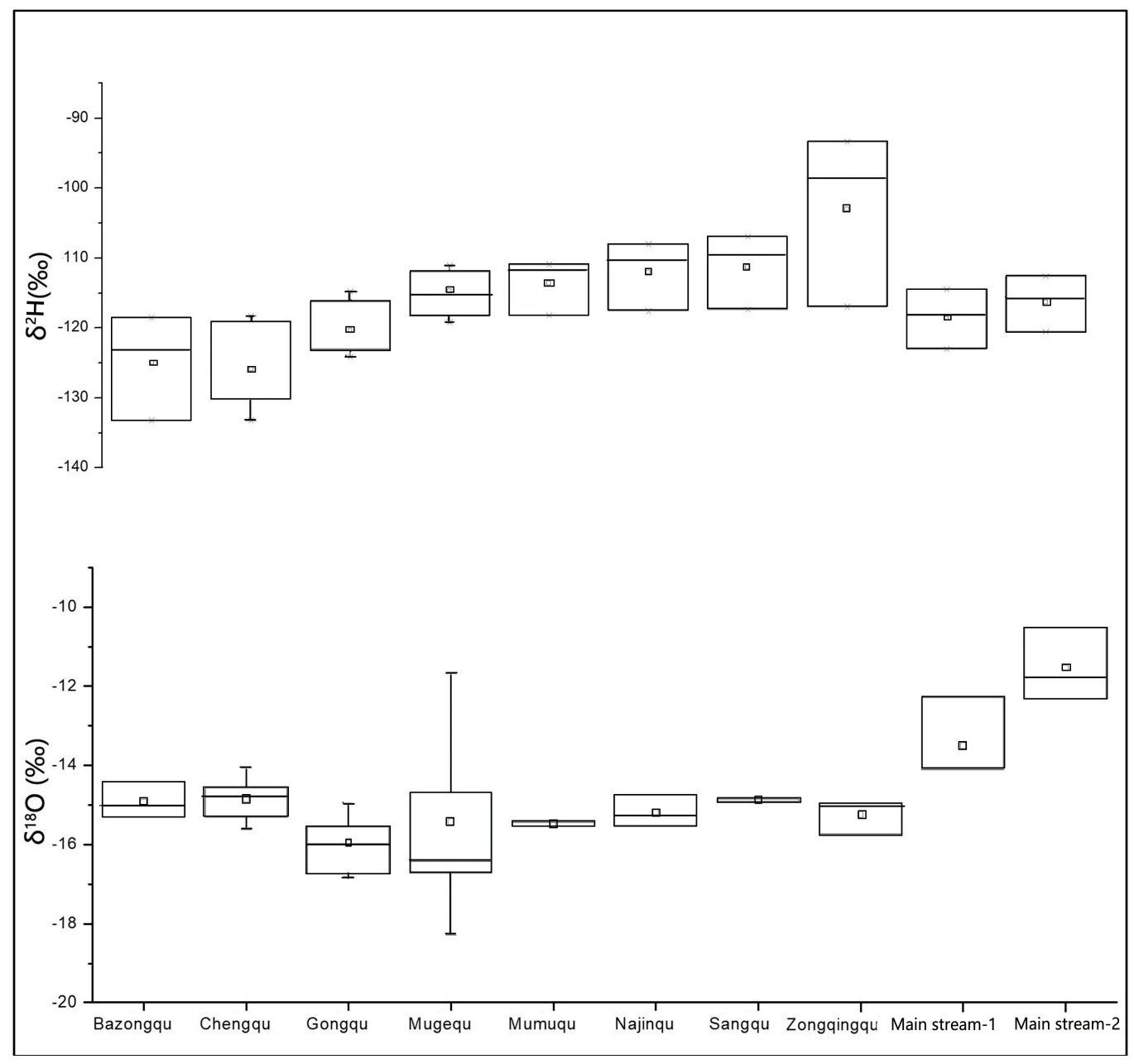

Figure 3. Box plots for $\delta^{2} \mathrm{H}$ and $\delta^{18} \mathrm{O}$ of runoff.

\subsection{Isotopic Characterization of River}

Craig [12] found that stable isotope ratios of $\delta^{18} \mathrm{O}$ and $\delta^{2} \mathrm{H}$ in precipitation correlate at a global scale in a linear relationship known as the global meteoric water line (GMWL). A linear relationship between $\delta^{18} \mathrm{O}$ and $\delta^{2} \mathrm{H}$ was established for average local meteoric waters as the local meteoric water line (LMWL). Important information about the water sources of precipitation can be revealed based on the deviation between LMWL and GMWL. By the location characteristics of different water samples, the water sources of rivers and the isotopic evaporative fractionation can be analyzed. In this paper, the LMWL of Lhasa region is adopted to replace the LMWL of the Naqu River basin. The LMWL can be described as: $\delta^{2} \mathrm{H}=7.9 \delta^{18} \mathrm{O}+6.29$ [43]. Compared to the LMWL, some sets of isotopic data with high $\delta^{18} \mathrm{O}$ values are below the LMWL, which signifies the effect of intensive evaporation processes.

By comparing different water samples with the LMWL, the water sources of the river and the isotopic evaporative fractionation can be analyzed. Most of the river sampling sites are close to LMWL $\left(\delta^{2} \mathrm{H}=7.9 \delta^{18} \mathrm{O}+6.29\right)$ (Figure 4). At the same time, many samples are close to each other, indicating that the water sources of these tributaries are relatively similar. The river water line is $\delta^{2} \mathrm{H}=5.75 \delta^{18} \mathrm{O}$ - 27.98. The groundwater and snowmelt samples are distributed around the river samples, indicating that the water is originated from local rainfall and runoff is recharged by groundwater, snowmelt, and precipitation. 


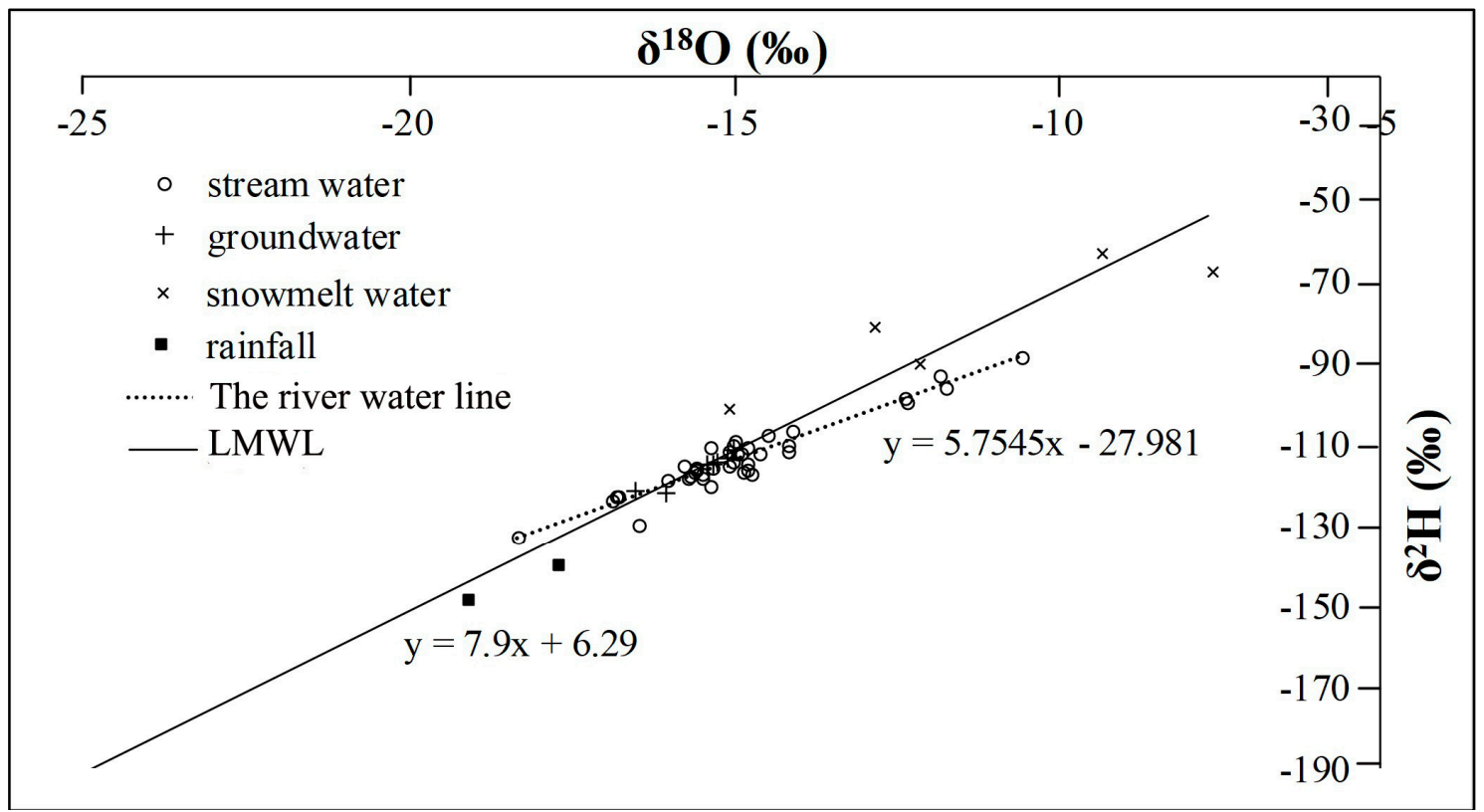

Figure 4. Plot of $\delta^{2} \mathrm{H}$ versus $\delta^{18} \mathrm{O}$ for different water sources.

The isotopic values of river water samples are closer to groundwater than those of snowmelt, indicating the frequent interaction between groundwater and runoff (Figure 4). Meanwhile, the slope and intercept are both smaller than that of LMWL, indicating that the water body in the Naqu River basin have experienced an obvious evaporation process.

The isotopes of snowmelt in winter appear to be the most enriched compared with other water sources, which is due to evaporation. When the snow begins to melt, the influence of evaporative fractionation increases, and the content of heavy isotopes in the meltwater increases.

\subsection{Hydrograph Separation}

Based on the formulas provided above, we calculated the contributions of rain, groundwater, and snowmelt by isotopic hydrograph separation in 2018 (Table 3, Figure 5). The proportion of snowmelt in runoff components ranges from $15 \%$ to $47 \%$, and the proportion of rainwater ranges from $3 \%$ to $35 \%$. The main components of runoff in the Naqu River are snowmelt and groundwater.

Table 3. Contribution of different water sources $\left({ }^{2} \mathrm{H}, \%\right.$; $\left.\mathrm{EC}, \mathrm{ms} / \mathrm{cm}\right)$.

\begin{tabular}{ccccccccccccc}
\hline Tributary & $\begin{array}{c}\text { Mean } \\
\text { Elevation }\end{array}$ & \multicolumn{2}{c}{ River Water } & \multicolumn{2}{c}{ Snowmelt } & \multicolumn{2}{c}{ Groundwater } & & Rainfall & Contribution (\%) \\
& (m a.s.1.) & D & EC & D & EC & D & EC & D & EC & Snowmelt & Groundwater & Rainfall \\
\hline Bazongqu & 4622 & -112 & 0.21 & -87 & 0.12 & -122 & 0.50 & -144 & 0.01 & $45 \%$ & $30 \%$ & $24 \%$ \\
Chengqu & 4519 & -115 & 0.31 & -87 & 0.12 & -122 & 0.50 & -144 & 0.01 & $29 \%$ & $56 \%$ & $16 \%$ \\
Gongqu & 4578 & -119 & 0.22 & -87 & 0.12 & -122 & 0.50 & -144 & 0.01 & $29 \%$ & $36 \%$ & $35 \%$ \\
Mugequ & 4609 & -121 & 0.31 & -87 & 0.12 & -122 & 0.50 & -144 & 0.01 & $18 \%$ & $58 \%$ & $24 \%$ \\
Mumuqu & 4712 & -117 & 0.43 & -87 & 0.12 & -122 & 0.50 & -144 & 0.01 & $15 \%$ & $82 \%$ & $3 \%$ \\
Najinqu & 4771 & -114 & 0.21 & -87 & 0.12 & -122 & 0.50 & -144 & 0.01 & $40 \%$ & $32 \%$ & $29 \%$ \\
Sangqu & 4626 & -112 & 0.21 & -87 & 0.12 & -122 & 0.50 & -144 & 0.01 & $45 \%$ & $30 \%$ & $25 \%$ \\
Zongqingqu & 4567 & -113 & 0.17 & -87 & 0.12 & -122 & 0.50 & -144 & 0.01 & $46 \%$ & $23 \%$ & $31 \%$ \\
\hline
\end{tabular}




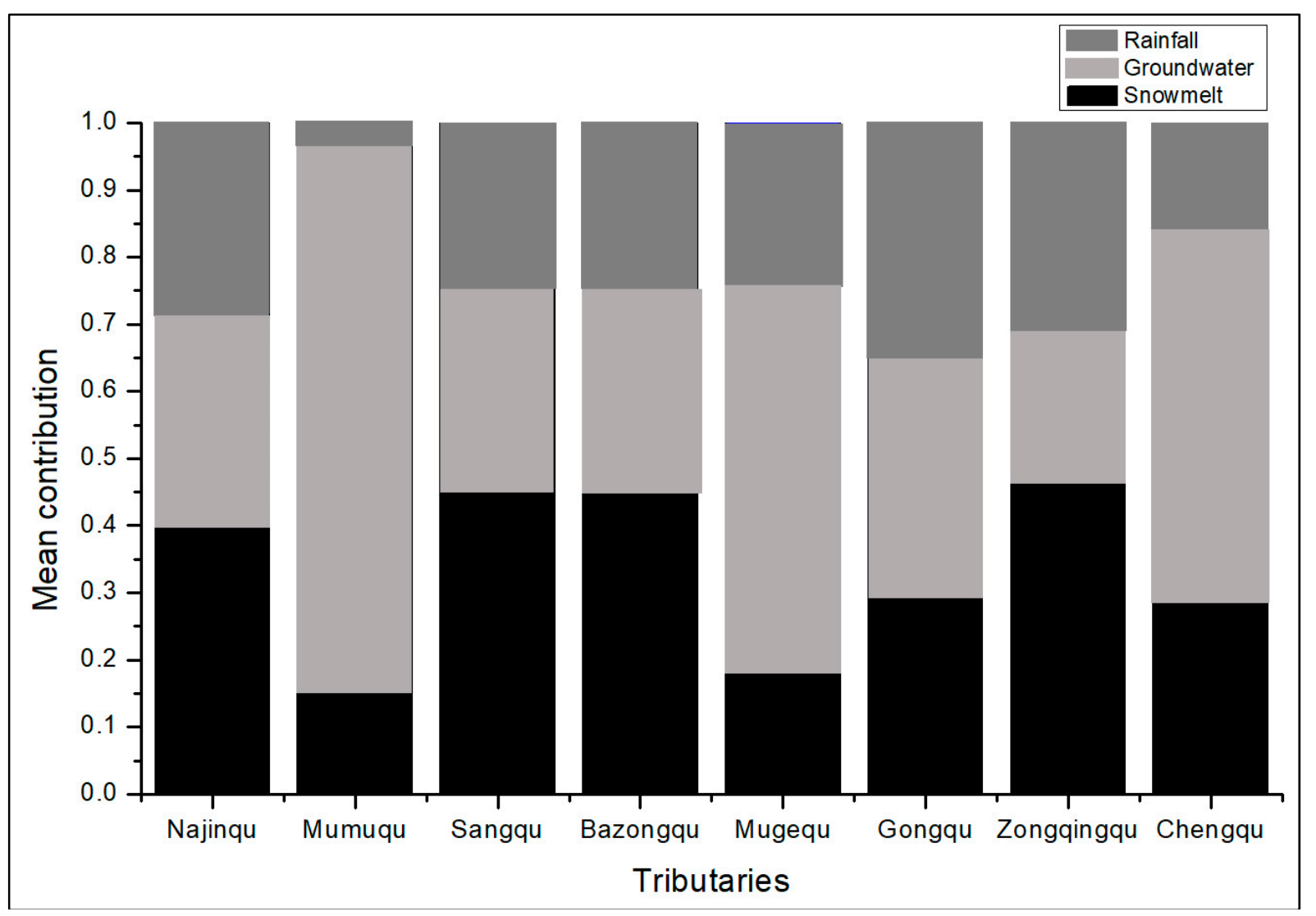

Figure 5. Contribution of different water sources.

\section{Discussion}

\subsection{Analysis of Spatial Variations of $\delta^{2} H$ and $\delta^{18} \mathrm{O}$ Values of the River}

Our analysis showed an insignificant spatial trend of either $\delta^{2} \mathrm{H}$ or $\delta^{18} \mathrm{O}$ among tributaries Najinqu, Sangqu, Bazongqu, Mumuqu, Chengqu, Zongqungqu, Mugequ, and Gongqu in August. However, there is a significant spatial variation trend based on one-way ANOVA between Main stream-2 and tributaries (Najinqu, Sangqu, Bazongqu, Mumuqu, Chengqu, Zongqungqu, Mugequ, and Gongqu) (Figure 3). Although elevation effects play an important role in isotopic variation in large topographic area, there was no obvious elevation effects between Main stream-2 and tributaries (Figure 2). Surface and groundwater samples are often below the LMWL and GMWL under intense evaporative fractionation and low humidity. In the Naqu River, some water samples deviate from the LMWL, and the waters experience intense evaporative fractionation due to the slow river flow rate.

For groundwater, the $\delta^{18} \mathrm{O}$ values were relatively stable, ranging from $-19.03 \%$ o to $-17.66 \%$, indicating that the surrounding environment has little influence on groundwater and the recharge source of groundwater is relatively stable (Table 1)., The groundwater was recharged by old water stored in the basin previously.

\subsection{Estimation of Different Water Sources Contribution to the River Flow}

Based on the analysis of runoff components, runoff of the Naqu River can be divided into three water sources by isotopic hydrograph separation: Groundwater, rain, and snowmelt. The calculation results show that snowmelt of most tributaries contributed more than $30 \%$ to the runoff, while the proportion of rain ranges from 3\% to $35 \%$ in the Naqu River basin. The results of hydrologic separation show that during the wet season, the river sources are mainly meltwater, and groundwater, with groundwater accounting for the largest proportion (more than 50\%). Groundwater and snowmelt 
account for a greater proportion of runoff composition in the Naqu River basin. Such results are different from the runoff data collected at the hydrological station (Figure 6). In the past, we believed that the changing trend of runoff was completely controlled by precipitation. We speculate that the main components of runoff are snowmelt water and groundwater, while rain affects the change of runoff in the Naqu River.

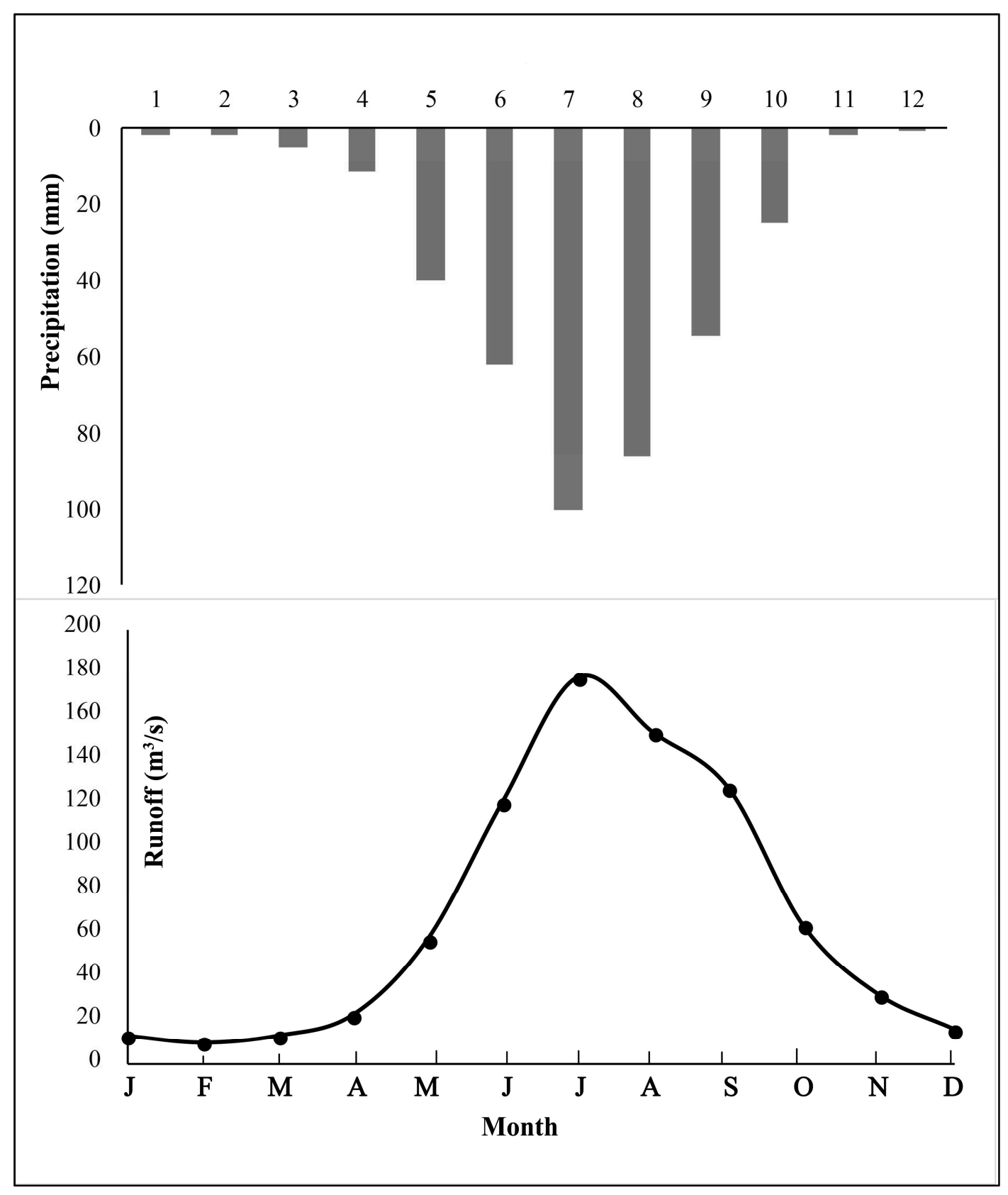

Figure 6. Monthly variations of precipitation and runoff in the Naqu River basin.

As shown in Figure 7, the contributions of groundwater of Mumuqu, Mugequ, and Chengqu are bigger than those of other tributaries. The contributions of snowmelt of Najinqu, Sangqu, Bazongqu, and Zongqingqu Rivers are bigger than those of other tributaries. We speculate that this phenomenon is related to the elevation characteristics of the Naqu River basin (Figure 1). At lower altitudes to the south, the recharge of groundwater in the river is stronger. The loose structure of the rocks, large areas of grassland, and abundant melt-water make the area relatively permeable. At higher altitudes in the north and east, the recharge of snowmelt to the river is stronger. The results of elevation effect 
analysis on the collected samples of the main stream and tributaries showed that isotopes in runoff do not change with elevation. There is a certain correlation between runoff composition and elevation, particularly related to the proportion of groundwater and snowmelt. Groundwater contributes more to the river in the central and western regions. Spatially, in the Naqu River, meltwater contributes more than $30 \%$ to runoff in the north, east, and south. Our results show that the groundwater and snowmelt water have different dominant effects on runoff composition from the upper to the lower reaches in the Naqu River. And the results can be referred to for near-future assessments of changes in discharge in the basin.

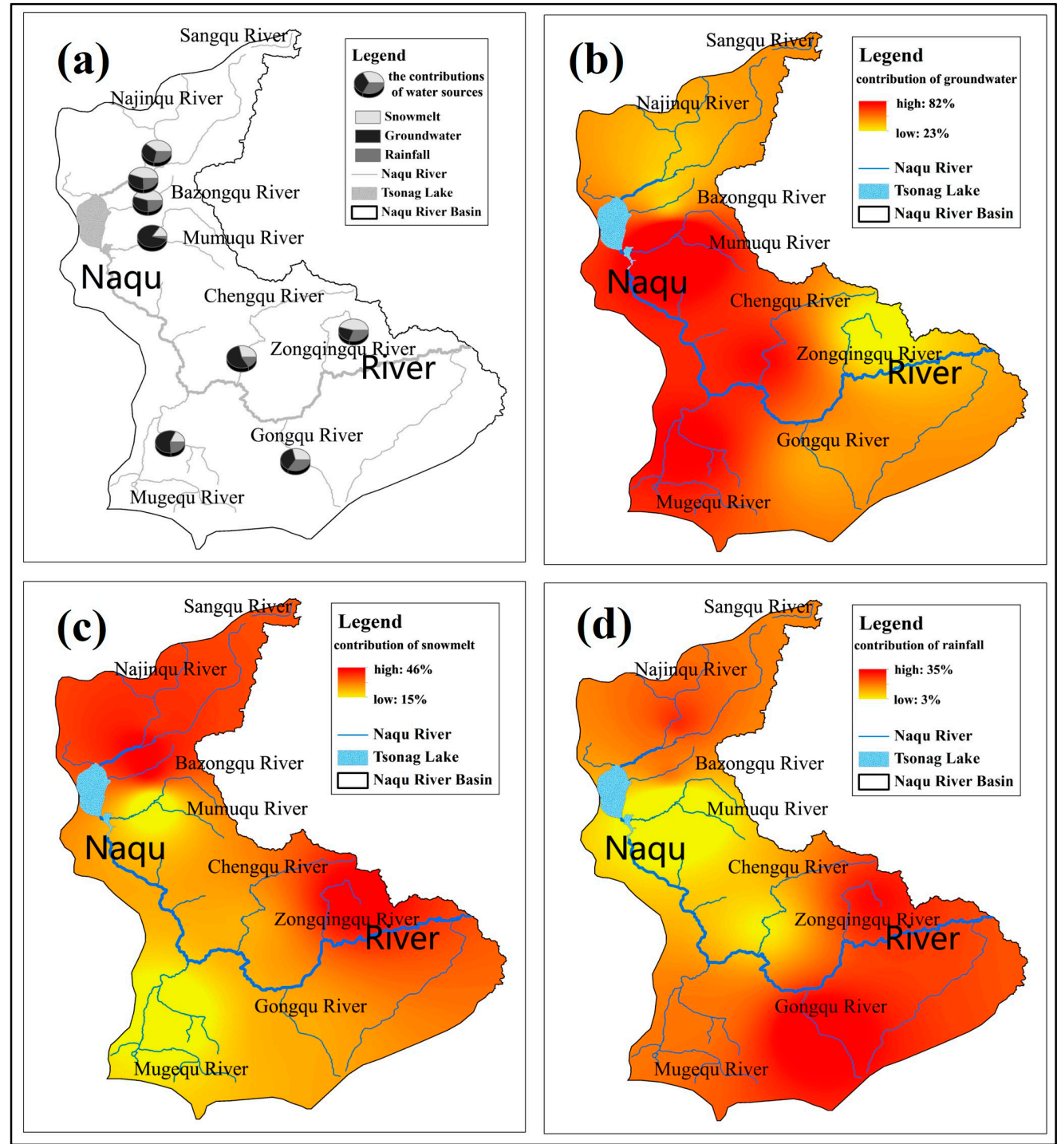

Figure 7. Spatial variation of contributions of numerous water sources in the Naqu River basin: (a) numerous water sources (b) groundwater, (c) snowmelt, and (d) rainfall.

\section{Conclusions}

We analyze the spatial variations of $\delta^{2} \mathrm{H}$ and $\delta^{18} \mathrm{O}$ with influencing factors and the sources of runoff in August, 2016-2018, for the Naqu River at the source of the Nu River on the Qinghai-Tibet. Our analysis showed an insignificant spatial trend of either $\delta^{2} \mathrm{H}$ or $\delta^{18} \mathrm{O}$ values among the tributaries Najinqu, Sangqu, Bazongqu, Mumuqu, Chengqu, Zongqungqu, Mugequ, and Gongqu in August. However, there is a significant spatial variation trend based on one-way ANOVA at 13 sampling sites between Main stream-2 and tributaries (Najinqu, Sangqu, Bazongqu, Mumuqu, Chengqu, Zongqungqu, 
Mugequ, and Gongqu). Isotopic evaporative fractionation in water and mixing of different water sources are the reasons for the spatial difference of isotopic values between Main stream- 2 and tributaries. Runoff of the Naqu River can be divided into three water sources: Groundwater, rainwater, and snowmelt. The proportion of snowmelt in runoff components ranges from $15 \%$ to $47 \%$, and the proportion of rainwater ranges from 3\% to $35 \%$. Thus, the main components of runoff are snowmelt and groundwater, while rain affects the change of runoff.

Author Contributions: X.C. and F.W. conceived, designed, and drafted the manuscript; X.C., G.W., D.Y. and H.Z. planned and designed the methodology; X.C. revised the manuscript; F.W. guided and supervised the whole process; and all authors read and approved the final manuscript.

Funding: This work was supported by the National Natural Science Foundation of People's Republic of China (51879106, 51709111), the Major Research Plan of the National Natural Science Foundation of China (91547209), National Key Research and Development Program of China (2016YFC0401401), the Distinguished Young Scholar of Science and Technology Innovation (184100510014), the Science and Technology Innovation Team in Universities of Henan Province (20IRTSTHN010).

Acknowledgments: The authors would like to express their sincere gratitude to the anonymous reviewers for their constructive comments and useful suggestions that helped us improve our paper.

Conflicts of Interest: No conflict of interest exists in the submission of this manuscript, and the manuscript is approved by all authors for publication.

\section{References}

1. Kong, Y.; Pang, Z. Evaluating the sensitivity of glacier rivers to climate change based on hydrograph separation of discharge. J. Hydrol. 2012, 434, 121-129. [CrossRef]

2. Wang, X.; Li, Z.; Ross, E.; Tayier, R.; Zhou, P. Characteristics of water isotopes and hydrograph separation during the spring flood period in Yushugou River basin, Eastern Tianshans, China. J. Earth Syst. Sci. 2015, 124, 115-124. [CrossRef]

3. Wang, Z.; Zhou, C.; Guan, B.; Deng, Z.; Zhi, Y.; Liu, Y.; Xu, C.; Fang, S.; Xu, Z.; Yang, H. The Headwater Loss of the Western Plateau Exacerbates China's Long Thirst. AMBIO 2006, 35, 271. [PubMed]

4. Zhou, J.; Wu, J.; Liu, S.; Zeng, G.; Qin, J.; Wang, X.; Zhao, Q. Hydrograph Separation in the Headwaters of the Shule River Basin: Combining Water Chemistry and Stable Isotopes. Adv. Meteorol. 2015, 2015, 1-10. [CrossRef]

5. Barthold, F.K.; Wu, J.K.; Vaché, K.B.; Schneider, K.; Frede, H.G.; Breuer, L.; Tetzlaff, D.; Carey, S.K.; Laudon, H.; Mcguire, K. Identification of geographic runoff sources in a data sparse region: Hydrological processes and the limitations of tracer-based approaches. Hydrol. Process. 2010, 24, 2313-2327. [CrossRef]

6. Pu, T.; He, Y.; Zhu, G.; Zhang, N.; Du, J.; Wang, C. Characteristics of water stable isotopes and hydrograph separation in Baishui catchment during the wet season in Mt.Yulong region, south western China. Hydrol. Process. 2013, 27, 3641-3648. [CrossRef]

7. Buttle, J.M. Isotope hydrograph separations and rapid delivery of pre-event water from drainage basins. Progr. Phys. Geogr. 1994, 18, 16-41. [CrossRef]

8. Liu, Y.; Fan, N.; An, S.; Bai, X.; Liu, F.; Xu, Z.; Wang, Z.; Liu, S. Characteristics of water isotopes and hydrograph separation during the wet season in the Heishui River, China. J. Hydrol. 2008, 353, 314-321. [CrossRef]

9. Sun, C.; Chen, Y.; Li, W.; Li, X.; Yang, Y. Isotopic time series partitioning of streamflow components under regional climate change in the Urumqi River, northwest China. Hydrol. Sci. J. 2016, 61, 1443-1459.

10. Wu, H.; Zhang, X.; Li, X.; Li, G.; Huang, Y. Seasonal variations of deuterium and oxygen-18 isotopes and their response to moisture source for precipitation events in the subtropical monsoon region. Hydrol. Process. 2015, 29, 90-102. [CrossRef]

11. James, C. Hydrogeological Conceptual Model of Groundwater from Carbonate Aquifers Using Environmental Isotopes $\left({ }^{18} \mathrm{O},{ }^{2} \mathrm{H}\right)$ and Chemical Tracers: A Case Study in Southern Latium Region, Central Italy. J. Water Resour. Prot. 2012, 4, 695-716.

12. Craig, H. Isotopic variations in meteoric waters. Science 1961, 133, 1702-1703. [CrossRef] [PubMed]

13. Longinelli, A.; Selmo, E. Isotopic composition of precipitation in Italy: A first overall map. J. Hydrol. 2003, $270,75-88$. 
14. Gibson, J.J.; Edwards, T.W.D.; Birks, S.J.; St Amour, N.A.; Buhay, W.M.; McEachern, P.; Wolfe, B.B.; Peters, D.L. Progress in isotope tracer hydrology in Canada. Hydrol. Process. 2005, 19, 303-327. [CrossRef]

15. Rank, D.; Wyhlidal, S.; Schott, K.; Weigand, S.; Oblin, A. Temporal and spatial distribution of isotopes in river water in Central Europe: 50 years experience with the Austrian network of isotopes in rivers. Isot. Environ. Health Stud. 2018, 54, 115-136. [CrossRef]

16. Zhang, W.; Cheng, B.; Hu, Z.; An, S.; Xu, Z.; Zhao, Y.; Cui, J.; Xu, Q. Using stable isotopes to determine the water sources in alpine ecosystems on the east Qinghai-Tibet plateau, China. Hydrol. Process. 2010, 24, 3270-3280. [CrossRef]

17. Kendall, C.; Coplen, T.B. Distribution of oxygen-18 and deuterium in river waters across the United States. Hydrol. Process. 2001, 15, 1363-1393. [CrossRef]

18. Liu, W.; Chen, S.; Xiang, Q.; Baumann, F.; Scholten, T.; Zhou, Z.; Sun, W.; Zhang, T.; Ren, J.; Qin, D. Storage, patterns, and control of soil organic carbon and nitrogen in the northeastern margin of the Qinghai-Tibetan Plateau. Environ. Res. Lett. 2012, 7, 35401-35412. [CrossRef]

19. Dansgaard, W. Stable isotopes in precipitation. Tellus 1964, 16, 436-468. [CrossRef]

20. Price, R.M.; Swart, P.K.; Willoughby, H.E. Seasonal and spatial variation in the stable isotopic composition $\left(\delta^{18} \mathrm{O}\right.$ and $\left.\delta^{2} \mathrm{H}\right)$ of precipitation in south Florida. J. Hydrol. 2008, 358, 193-205. [CrossRef]

21. Song, X.; Kayane, I.; Tanaka, T.; Shimada, J. A study of the ground cycle in Sri Lanka using stable isotopes. Hydrol. Process. 2015, 13, 1479-1496. [CrossRef]

22. Harrington, G.A.; Cook, P.G.; Herczeg, A.L. Spatial and temporal variability of ground water recharge in central Australia: A tracer approach. Groundwater 2010, 40, 518-527. [CrossRef] [PubMed]

23. He, Y.; Theakstone, W.H.; Yao, T.; Shi, Y. The isotopic record at an alpine glacier and its implications for local climatic changes and isotopic homogenization processes. J. Glaciol. 2017, 47, 147-151.

24. Fan, Z.; Ma, Y. Some Issues about the Exploitation and the Rational Utilization of Water Resources in the Arid Areas. Arid Zone Res. 2000, 17, 6-11.

25. Xu, Q. Application of Environmental Isotopes in Water Cycle of Forest Ecosystem. World For. Res. 2008, 21, $11-15$.

26. Han, G.; Lv, P.; Tang, Y.; Song, Z. Spatial and temporal variation of H and O isotopic compositions of the Xijiang River system, Southwest China. Isot. Environ. Health Stud. 2018, 54, 137-146. [CrossRef] [PubMed]

27. Qu, S.; Wang, Y.; Zhou, M.; Liu, H.; Shi, P.; Yu, Z.; Xiang, L. Temporal ${ }^{18} \mathrm{O}$ and deuterium variations in hydrologic components of a small watershed during a typhoon event. Isot. Environ. Health Stud. 2017, 53, 172-183. [CrossRef]

28. Yang, Y.; Xiao, H.; Qin, Z.; Zou, S. Hydrogen and oxygen isotopic records in monthly scales variations of hydrological characteristics in the different landscape zones of alpine cold regions. J. Hydrol. 2013, 499, 124-131. [CrossRef]

29. Meredith, K.T.; Hollins, S.E.; Hughes, C.E.; Cendón, D.I.; Chisari, R.; Griffiths, A.; Crawford, J. Evaporation and concentration gradients created by episodic river recharge in a semi-arid zone aquifer: Insights from $\mathrm{Cl}^{-}, \delta^{18} \mathrm{O}, \delta^{2} \mathrm{H}$, and ${ }^{3} \mathrm{H}$. J. Hydrol. 2015, 529, 1070-1078. [CrossRef]

30. Biggs, T.W.; Lai, C.T.; Chandan, P.; Lee, R.M.; Messina, A.; Lesher, R.S.; Khatoon, N. Evaporative fractions and elevation effects on stable isotopes of high elevation lakes and streams in arid western Himalaya. J. Hydrol. 2015, 522, 239-249. [CrossRef]

31. Edirisinghe, E.A.; Pitawala, H.M.; Dharmagunawardhane, H.A.; Wijayawardane, R.L. Spatial and temporal variation in the stable isotope composition $\left(\delta^{18} \mathrm{O}\right.$ and $\left.\delta^{2} \mathrm{H}\right)$ of rain across the tropical island of Sri Lanka. Isot. Environ. Health Stud. 2017, 53, 628-645. [CrossRef] [PubMed]

32. Wassenaar, L.I.; Athanasopoulos, P.; Hendry, M.J. Isotope hydrology of precipitation, surface and ground waters in the Okanagan Valley, British Columbia, Canada. J. Hydrol. 2011, 411, 37-48. [CrossRef]

33. Sánchez-Murillo, R.; Esquivel-Hernández, G.; Sáenz-Rosales, O.; Piedra-Marín, G.; Fonseca-Sánchez, A.; Madrigal-Solís, H.; Ulloa-Chaverri, F.; Rojas-Jiménez, L.D.; Vargas-Víquez, J.A. Isotopic composition in precipitation and groundwater in the northern mountainous region of the Central Valley of Costa Rica. Isot. Environ. Health Stud. 2016, 53, 1-17. [CrossRef] [PubMed]

34. Jin, L.; Siegel, D.I.; Lautz, L.K.; Lu, Z. Identifying streamflow sources during spring snowmelt using water chemistry and isotopic composition in semi-arid mountain streams. J. Hydrol. 2012, 470, 289-301. [CrossRef]

35. Rock, L.; Mayer, B. Isotope hydrology of the Oldman River basin, southern Alberta, Canada. Hydrol. Process. 2010, 21, 3301-3315. [CrossRef] 
36. Pinder, G.F.; Jones, J.F. Determination of the Ground-Water Component of Peak Discharge from the Chemistry of Total Runoff. Water Resour. Res. 1969, 5, 438-445. [CrossRef]

37. Aggarwal, P.K. Isotope hydrology at the International Atomic Energy Agency. Hydrol. Process. 2002, 16, 2257-2259. [CrossRef]

38. Christophersen, N.; Hooper, R.P. Multivariate Analysis of Stream Water Chemical Data: The Use of Principal Component Analysis for the End-Member Mixing Problem. Water Resour. Res. 1992, 28, 99-107. [CrossRef]

39. Chen, X.; Wang, G.; Wang, F. Classification of Stable Isotopes and Identification of Water Replenishment in the Naqu River Basin, Qinghai-Tibet Plateau. Water 2019, 11, 46. [CrossRef]

40. Vespasiano, G.; Apollaro, C.; De Rosa, R.; Muto, F.; Larosa, S.; Fiebig, J.; Mulch, A.; Marini, L. The Small Spring Method (SSM) for the definition of stable isotope-elevation relationships in Northern Calabria (Southern Italy). Appl. Geochem. 2015, 63, 333-346. [CrossRef]

41. Vespasiano, G.; Apollaro, C.; Muto, F.; Dotsika, E.; De Rosa, R.; Marini, L. Chemical and isotopic characteristics of the warm and cold waters of the Luigiane Spa near Guardia Piemontese (Calabria, Italy) in a complex faulted geological framework. Appl. Geochem. 2014, 41, 73-88. [CrossRef]

42. Apollaro, C.; Dotsika, E.; Marini, L.; Barca, D.; Bloise, A.; De Rosa, R.; Doveri, M.; Lelli, M.; Muto, F. Chemical and isotopic characterization of the thermo mineral water of Terme Sibarite springs (Northern Calabria, Italy). Geochem. J. 2012, 46, 117-129. [CrossRef]

43. Li-De, T.; Shan-Dong, Y.; Wei-Zhen, S.; Stievenard, M.; Jouzel, J. Relationship between $\delta^{2} \mathrm{H}$ and $\delta^{18} \mathrm{O}$ and water vapour circulation in the precipitation of the qinghai-tibet plateau. Sci. Sin. Terrae 2001, 31, $214-220$.

(C) 2019 by the authors. Licensee MDPI, Basel, Switzerland. This article is an open access article distributed under the terms and conditions of the Creative Commons Attribution (CC BY) license (http://creativecommons.org/licenses/by/4.0/). 